He then turned to the Cretaceous Asteroidea, com. pleting (1905-7) for the Palæontographical Society the monograph on that group which had been begun by W. Percy Sladen in 1891-93. The evolution of these forms was the subject of a subsequent paper in the Phil. Trans. Roy. Soc. (1913). His major work was his monograph of the British Palæozoic Asterozoa, ten parts of which were published by the Palæontographical Society between 1914 and 1940, when the War made further progress impossible. Spencer's last work, in which he described and discussed the earliest known starfishes, which occur in the Lower Ordovician of southern France and Bohemia, was published in 1951 by the Royal Society.

Spencer's work was concerned largely with ancient and often indifferently preserved fossils; but he was an adept at getting the most out of his material and always regarded the subjects of his researches primarily as animals which had once lived in harmony with their environment, and the functional significance of every structure of which demanded interpretation. The skilful reconstructions of these animals and their organs, well depicted under his guidance by his artist, F. T. Jones (an Ipswich art master), are a notable feature of his papers. $\mathrm{He}$ received his Oxford doctorate and the Lyell Award of the Geological Society of London in 1918, and in 1931 was elected to the fellowship of the Royal Society.

L. R. Cox

\section{Mr. R. B. Pilcher, O.B.E.}

THE name of Richard Bertram Pilcher, who died at his home in Northwood on October 1 in his eightysecond year, will remain indelibly impressed on the records of two distinct professional organizationsthe Royal Institute of Chemistry and the Chartered Institute of Secretaries. A native of Patrixbourne, near Canterbury, he was appointed clerk to the Institute of Chemistry in 1892 and became successively assistant secretary (1894), secretary (1895) and registrar and secretary (1900-45). Pilcher had known all the presidents from 1877 onwards, and from his youth completely identified himself with the profession and with its interests and aspirations. His tall, lean and dignified figure, with a hint of the ascetic, due more to the delicate state of his health in early manhood than to any avoidance of the pleasures of life, was well known in scientific and official circles for many decades.

During the First World War the Institute became the chief agency whereby the various ministries and Government departments obtained chemists, and Pilcher, then secretary to the Glass Research Committee, was in constant demand. After the War he interested himself in the re-settlement of officers and other careers matters, serving on committees of the Ministry of Labour. He was appointed O.B.E. in 1920. He served as honorary secretary of the Chemical Council from its inception in 1935 until 1943. He became a member of the Parliamentary and Scientific Committee in 1935, and a vice-president in 1943. In 1952 the Institute paid tribute to his long service and abiding interest in the profession by admitting him as one of its first honorary Fellows.

An avid reader, fond of honest labour, and prone to contemplation, his pen never rested long. Several of his compilations became standard reference works, passing through a number of editions. Among these were "Official Chemical Appointments" (1906); the joint work "What Industry Owes to Chemical Science" (1918) ; and "The Profession of Chemistry" (1919). Having a keen interest in the history of chemistry, and particularly in chemical biography and iconography, he acquired a mass of manuscript, material and a well-known collection of prints.

A Fellow of the (then) Institute of Secretaries in 1897, Pilcher served it as a member of council from 1908, as vice-president $(1924-26)$ and as president (1926-27). He introduced the system of registered studentship, and was ever pleased to think that many thousands of young people had thereby increased their knowledge and worth to the community. He was also a past chairman of council of the Association of Men of Kent and Kentish Men.

Pilcher was intensely human and loved all growing things. This, perhaps, provides a clue to the main interests of his life-children and flowers; students and the history of science ; the nurturing and service of two rapidly expanding professional organizations : in these matters his years did not weary him nor diminish his ardour. $\mathrm{He}$ is survived by his widow, Violet Frances, two sons and a daughter.

\section{F. W. GrBBs}

\section{NEWS}

\section{Royal Society: Award of Royal Medals}

H.M. THE QUEen has been graciously pleased to approve recommendations made by the Council of the Royal Society for the award of the two Royal Medals for the current year as follows : Sir Alexander Todd, professor of chemistry, University of Cambridge, for his distinguished work in organic chemistry ; Prof. V. B. Wigglesworth, Quick professor of biology, University of Cambridge, for his distinguished experimental contributions of outstanding value to many aspects of insect physiology.

\section{Electronic Engineering at Liverpool:}

Prof. J. D. Craggs

THe Robert Rankin chair of electronic engineering in the University of Liverpool has been filled by the appointment of Dr. J. D. Craggs, formerly reader in electronic engineering. Dr. Craggs graduated in 1937

\section{and VIEWS}

in the University of London and, after a year's research in the Mechanical Engineering Department at King's College, London, he was awarded a Department of Scientific and Industrial Research grant to enable him to work under the direction of Sir Charles Ellis on the development of a high-voltage accelerator for nuclear research. This work was carried out in the Research Department of the Metropolitan-Vickers Electrical Co. at Trafford Park, Manchester. In 1940 Dr. Craggs joined the research staff of this Company and continued to work on the accelerator until 1941, when he became concerned with the development of high-power spark modulators for radar. During 1944-45 he spent six months in the University of California, Berkeley, on studies of collision process connected with the uranium fission programme. In 1945 he returned to the Metropolitan-Vickers Research Department and was responsible for the construction of a $20-\mathrm{MeV}$. betatron. He also carried out work on 